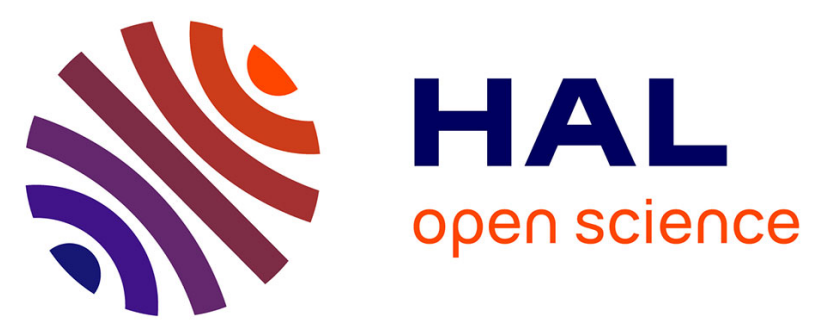

\title{
Apoptosis and p53 are not involved in the anti-tumor efficacy of (125)I-labeled monoclonal antibodies targeting the cell membrane.
}

Salomé Paillas, Vincent Boudousq, Bérengère Piron, Nathalie Kersual, Manuel Bardiès, Nicolas Chouin, Caroline Bascoul-Mollevi, François-Xavier Arnaud, André Pèlegrin, Isabelle Navarro-Teulon, et al.

\section{To cite this version:}

Salomé Paillas, Vincent Boudousq, Bérengère Piron, Nathalie Kersual, Manuel Bardiès, et al.. Apoptosis and p53 are not involved in the anti-tumor efficacy of (125)I-labeled monoclonal antibodies targeting the cell membrane.: Running title: 125I-RIT-induced cell death mechanisms. Nuclear Medicine and Biology, 2013, epub ahead of print. 10.1016/j.nucmedbio.2013.02.001 . inserm-00815724

\section{HAL Id: inserm-00815724 https://www.hal.inserm.fr/inserm-00815724}

Submitted on 19 Apr 2013

HAL is a multi-disciplinary open access archive for the deposit and dissemination of scientific research documents, whether they are published or not. The documents may come from teaching and research institutions in France or abroad, or from public or private research centers.
L'archive ouverte pluridisciplinaire HAL, est destinée au dépôt et à la diffusion de documents scientifiques de niveau recherche, publiés ou non, émanant des établissements d'enseignement et de recherche français ou étrangers, des laboratoires publics ou privés. 
Apoptosis and p53 are not involved in the anti-tumor efficacy of ${ }^{125}$ I-labeled monoclonal antibodies targeting the cell membrane

Bérengère Piron $^{\mathrm{a}^{*}}$, Salomé Paillas ${ }^{\mathrm{a}^{*}}$, Nathalie Kersual ${ }^{\mathrm{a}}$, Manuel Bardiès ${ }^{\mathrm{c}}$, Nicolas Chouin ${ }^{\mathrm{d}}$, Caroline Bascoul-Mollevi ${ }^{\mathrm{b}}$, François-Xavier Arnaud ${ }^{\mathrm{e}}$, André Pèlegrin ${ }^{\mathrm{a}}$, Isabelle NavarroTeulon $^{\mathrm{a}}$, David Azria ${ }^{\mathrm{a}}$ and Jean-Pierre Pouget ${ }^{\mathrm{a}}$

a IRCM, Institut de Recherche en Cancérologie de Montpellier, Montpellier, F-34298, France; INSERM, U896, Montpellier, F-34298, France; Université Montpellier1, Montpellier, F34298, France; CRLC Val d'Aurelle Paul Lamarque, Montpellier, F-34298, France; ${ }^{\mathrm{b}}$ CRLC Val d'Aurelle-Paul Lamarque, F-34298 Montpellier, France; ' UMR 1037 INSERM/UPS, Toulouse, France; ${ }^{\mathrm{d}}$ LUNAM Université, Oniris, «AMaROC », Nantes, F-44307, France; ${ }^{\text {e }}$ Laboratoire Laplace, UMR 5213, Toulouse, F-31400, Université de Toulouse;

Running title: ${ }^{125}$ I-RIT-induced cell death mechanisms

Key words: Radioimmunotherapy, Auger electrons, p53, apoptosis, ${ }^{125} \mathrm{I}-\mathrm{mAbs}$

To whom correspondence may be addressed: Jean-Pierre Pouget, Institut de Recherche en Cancérologie de Montpellier, CRLC Val d'Aurelle, 34298 Montpellier Cedex 5, France. Tel: +33 (0)467 613 708; fax: +33 (0)467 613 787. E-mail address: jean-pierre.pouget@ inserm.fr

*: authors participated equally to this work 


\section{ABSTRACT}

Introduction: ${ }^{125}$ I-labeled monoclonal antibodies ( $\left.{ }^{125} \mathrm{I}-\mathrm{mAbs}\right)$ can efficiently treat small solid tumors. Here, we investigated the role of apoptosis, autophagy and mitotic catastrophe in ${ }^{125} \mathrm{I}-$ $\mathrm{mAb}$ toxicity in $p 53^{-/}$and $p 53^{+/+}$cancer cells.

Methods: We exposed $p 53^{-/}$and $p 53^{+/+}$HCT116 cells to increasing activities of internalizing (cytoplasmic location) anti-HER $1{ }^{125} \mathrm{I}-\mathrm{mAbs}$, or non-internalizing (cell surface location) antiCEA ${ }^{125} \mathrm{I}-\mathrm{mAbs}$. For each targeting model we established the relationship between survival and mean nucleus absorbed dose using the MIRD formalism.

Results: In both $p 53^{-/-}$and $p 53^{+/+}$HCT116 cells, anti-CEA ${ }^{125} \mathrm{I}-\mathrm{mAbs}$ were more cytotoxic per Gy than anti-HER $1{ }^{125}$ I-mAbs. Sensitivity to anti-CEA ${ }^{125}$ I-mAbs was p53-independent, while sensitivity to anti-HER $1{ }^{125} \mathrm{I}-\mathrm{mAbs}$ was higher in $p 53^{-/-}$HCT 116 cells, suggesting that they act through different signaling pathways. Apoptosis was only induced in $p 53^{+/+}$HCT116 cells and could not explain cell membrane radiation sensitivity. Inhibition of autophagy did not modify the cell response to ${ }^{125} \mathrm{I}-\mathrm{mAbs}$. By contrast, mitotic death was similarly induced in both $p 53^{-/}$and $p 53^{+/+}$HCT116 cells by the two types of ${ }^{125} \mathrm{I}-\mathrm{mAbs}$. We also showed using medium transfer experiments that $\gamma$ - $\mathrm{H} 2 \mathrm{AX}$ foci were produced in bystander cells.

Conclusion: Cell membrane sensitivity to ${ }^{125} \mathrm{I}-\mathrm{mAbs}$ is not mediated by apoptosis and is p53independent. Bystander effects-mediated mitotic death could be involved in the efficacy of ${ }^{125} \mathrm{I}-\mathrm{mAbs}$ binding cell surface receptors. 


\section{INTRODUCTION}

Radioimmunotherapy (RIT) is an innovative tool to deliver radiation specifically to diffuse or metastatic cancer cells by using monoclonal antibodies (mAbs) against tumor-associated antigens. However, RIT of solid tumors requires more complex approaches than RIT of radiation-sensitive hematopoietic malignancies (for reviews [18,21]).

High linear energy transfer (LET) particles, such as Auger electrons, have been used in several clinical trials to overcome the radio-resistance of solid tumors $[16,24,28,29]$. Auger electrons have a very low energy (from a few $\mathrm{eV}$ to few $\mathrm{keV}$ ) and those with energy below 1 $\mathrm{keV}$ are considered as high LET particles (from 4 to $26 \mathrm{keV} / \mu \mathrm{m}$ ). Their path length in biological matter is very short, between about $2 \mathrm{~nm}$ and $500 \mathrm{~nm}$ ([20] and for reviews see $[3,4,6,11,12,19,32])$, and they produce highly localized energy deposits. They have been mostly used for targeting the nucleus $[1,13,14]$. However, we previously showed that noninternalizing anti-CEA mAbs labeled with Auger electron emitters, such as ${ }^{125} \mathrm{I}$, can efficiently delay growth of small-volume tumors $(2-3 \mathrm{~mm}$ diameter $)[2,25]$. Since the final localization of ${ }^{125} \mathrm{I}$-labelled mAbs $\left({ }^{125} \mathrm{I}\right.$-mAbs) upon binding to their receptors is the cytoplasm (internalizing mAbs) or the cell membrane (non-internalizing mAbs), the high therapeutic efficacy of ${ }^{125} \mathrm{I}-\mathrm{mAbs}$ that do not target the nucleus was rather unexpected.

DNA is certainly the main target of radiation and DNA double-strand breaks (DSBs) constitute the most relevant lesions involved in cell killing. Unrepaired and misrepaired DNA DSBs lead to the formation of chromosomal aberrations that cause the loss of large amounts of genetic material, namely micronuclei, when such cells try to divide, leading to reproductive or mitotic cell death. Alternative mechanisms of radiation-induced cancer cell death may involve apoptosis, autophagy, senescence or necrosis (for reviews [5,8]). Their contribution depends on several physical and biological parameters, including cell type, absorbed dose, radiation and the cell p53 status. Necrosis is generally observed in cells after exposure to high 
absorbed doses, such as when using high LET alpha particles [26], while radiation-induced accelerated senescence is associated with irreversible cell cycle arrest and involves p53 activation and telomere shortening. As the role of autophagy in radiation-induced cell death is still controversial, apoptosis and mitotic death are considered the main mechanisms involved in RIT-induced cell death.

Radiation-induced apoptosis might explain the efficacy of ${ }^{90} \mathrm{Y}$-labelled ibritumomab tiuxetan (Zevalin $^{\circledR}$; Spectrum Pharmaceuticals, Ca, USA) and of ${ }^{131}$ I-labelled tositumomab (Bexxar ${ }^{\circledR}$; Glaxosmithkline LLC, NC, USA) for the treatment of non-Hodgkin lymphoma (for review [21]). Apoptosis can be initiated by intrinsic (involving mitochondria or upstream DNA damage) or extrinsic (involving binding of ligands to cell membrane death receptors, like CD95/Fas, KILLER/DR5) pathways that result in Caspase activation (for reviews [8,23]). Apoptosis can also be mediated by radiation directly deposited in the membrane via the activation of acid sphingomyelinase signaling and production of a $2^{\text {nd }}$ messenger [9]. Although it might be p53-independent, radiation-induced apoptosis is generally associated with p53 accumulation and activation, resulting in transactivation of pro-apoptotic genes. Apoptotic signaling initiated at the cell membrane could be particularly relevant in RIT with ${ }^{125} \mathrm{I}-\mathrm{mAbs}$ because mAbs target cell surface receptors before undergoing (in the case of internalizing mAbs) or not (non-internalizing mAbs) receptor-mediated internalization within the cytoplasm.

To investigate the cell death mechanisms involved in the efficacy of ${ }^{125} \mathrm{I}-\mathrm{mAbs}$, we exposed $p 53^{-/}$and $p 53^{+/+}$HCT116 cells to increasing activities $(0-4 \mathrm{MBq} / \mathrm{mL})$ of anti-HER1 (that rapidly internalize in the cytoplasm) or anti-CEA (that mainly remain at the cell surface) ${ }^{125} \mathrm{I}-$ mAbs. We then assessed the contribution of apoptosis, autophagy and mitotic catastrophe to RIT-induced cell death. At last, preliminary experiments investigated the role of bystander effects in ${ }^{125} \mathrm{I}-\mathrm{mAbs}$ efficacy using transfer medium protocol. 


\section{MATERIALS AND METHODS}

\section{Cell lines}

HCT116 $\left(p 53^{+/+}\right)$human colorectal cancer cells, A-431 vulvar squamous carcinoma and SKOV-3 ovarian carcinoma cells were from ATCC. The $p 53^{-/-}$HCT116 cell line was a gift from Professor Bert Vogelstein (Johns Hopkins University). A-431 and HCT116 cells express HER1, while SK-OV-3 cells express HER2 receptors. A-431 and SK-OV-3 cells were transfected with the vector encoding the Carcino-embryogenic antigen (CEA) as described in [22], while HCT116 cells express basal level of CEA receptors. A-431 and SK-OV-3 cells were grown as described in [22]. HCT116 cells were maintained in RPMI supplemented with $10 \%$ heat-inactivated FBS, $100 \mu \mathrm{g} / \mathrm{mL}$ L-glutamine and antibiotics $(0.1 \mathrm{unit} / \mathrm{mL}$ penicillin and $100 \mu \mathrm{g} / \mathrm{mL}$ streptomycin).

\section{Antibodies and radiolabeling}

Trastuzumab (Herceptin ${ }^{\circledR}$, Genentech Incorporated, San Francisco CA, USA) is a humanized IgG1k internalizing mAb against the Human Epidermal Receptor type 2 (HER2) expressed in SK-OV-3 cells. The hybridoma murine m225 mAb (from ATCC) binds to the Epidermal Growth Factor Receptor (EGFR/HER1) and was used for targeting A-431 and HCT116 cells. The non-internalizing murine $\operatorname{IgG} 1 \mathrm{k}$ mAb $35 \mathrm{~A} 7$ is specific for the CEA Gold 2 epitope $[10,22]$. The non-targeting IgG1 mAb PX was purified from the mouse myeloma P3-X63 line and used as control [15]. The m225, 35A7 and PX mAbs were obtained from mouse hybridoma ascite fluids by ammonium sulphate precipitation followed by ion exchange chromatography on DE52 cellulose (Whatman, Balston, United Kingdom).

Radiolabelling of mAbs was done according to the conventional IODO-GEN method $(1,3,4,6-$ tetrachloro-3 $\alpha, 6 \alpha$-diphenylglycoluryl) described in [22] and radiolabeled mAbs were used the 
same day as the experiments were performed. The specific activity of ${ }^{125}$ I-labelled mAbs was about $370 \mathrm{MBq} / \mathrm{mg}$ of protein and immunoreactivity was around $60-95 \%$.

\section{Clonogenic assay and cellular dosimetry}

Survival of cells treated with ${ }^{125} \mathrm{I}-\mathrm{mAbs}$ was assessed by standard clonogenic assay as described in [22]. The mean nucleus absorbed dose was calculated using the MIRD cellular approach [7] that requires the determination of the total cumulative number of decays $\left(\tilde{A}_{r s}\right)$ occurring in cells and the S-values. Then, for each test activity, the graphs plotting the radioactivity uptake per cell $(\mathrm{Bq} / \mathrm{cell})$ relative to time (d), determined as described in [22], were used to estimate $\tilde{A}_{r s}$ at different time points during the test period (6 days) by calculating the area under the curves. The 6-day test period allowed the radioactivity per cell to return to background level. For all targeting models, $\tilde{A}_{r s}$ was then multiplied by the corresponding $S$ value to obtain the mean nucleus absorbed dose. For S-value calculations, three sources of irradiation were considered: self-irradiation from radiolabelled vectors that were internalized in the cytoplasm or bound to the cell membrane; culture medium irradiation from unbound radiolabelled vectors; and cross-fire irradiation. Cell size was measured by fluorescence microscopy after propidium iodide staining and the cell radius (distributed normally within the HCT116 cell population) was $5.6 \pm 1.0 \mu \mathrm{m}$ when the nucleo-cytoplasmic ratio was about 0.65 .

\section{Energy deposition associated with anti-CEA ${ }^{125}$ I-mAbs}

We simulated the emission of $1 \times 10^{6}$ electrons by ${ }^{125} \mathrm{I}$ at the surface of a $5.6 \mu \mathrm{m}$ spherical cell radius (thus mimicking anti-CEA ${ }^{125} \mathrm{I}-\mathrm{mAbs}$ ) using the Geant4 Monte-Carlo code and "DNA" physics list adapted to very low energies (up to $\sim 8 \mathrm{eV}$ ) in liquid water. ${ }^{125}$ I spectra were taken from [20]. The cell was segmented into 5600 concentric shells in which the absorbed energy was scored. The cell membrane was estimated to be approximately $6 \mathrm{~nm}$ in width. 


\section{Micronucleus assay}

The method described in [22] was followed to determine the occurrence of micronuclei in cells exposed to activities between 0 and $4 \mathrm{MBq} / \mathrm{mL}$ of anti-CEA, anti-HER1 or non-targeting PX ${ }^{125} \mathrm{I}-\mathrm{mAbs}$ for 2 days. We calculated the cumulative frequency of micronuclei per binucleated cell over 3 days. Experiments were repeated three times in triplicate.

\section{Protein extraction and Western blot analysis}

Cells were washed twice with $1 \mathrm{~mL}$ ice-cold PBS and lysed with $200 \mu \mathrm{L}$ of buffer $(10 \mathrm{mM}$ EDTA, $40 \mathrm{mM}$ Tris, $40 \mathrm{mM} \mathrm{NaPPi}, 50 \mathrm{mM} \mathrm{NaF}, 5 \mathrm{mM} \mathrm{MgCl}_{2}, 100 \mu \mathrm{M}$ orthovanadate, $1 \%$ Triton $\mathrm{X} 100, \mathrm{H}_{2} \mathrm{O}$ ) and 1:1000 PIC. Samples were centrifuged at 10,000 $\times \mathrm{rpm}$ (round per minute) at $4^{\circ} \mathrm{C}$ for $5 \mathrm{~min}$. Protein concentration in supernatants was determined by the Bradford method (Bio-Rad Laboratories, NY, USA); $20 \mu \mathrm{g}$ of proteins were mixed with $2 \mathrm{X}$ buffer ( $25 \%$ glycerol, $4 \%$ SDS and $2 \%$ beta-mercaptoethanol) and boiled for $10 \mathrm{~min} .25 \mu \mathrm{L}$ of protein lysates were separated through SDS-polyacrylamide gels (40V, $500 \mathrm{~mA}$ for $120 \mathrm{~min}$ ) and transferred onto nitrocellulose membranes. Membranes were pre-incubated with $5 \%$ milk in PBS/0.1\% Tween 20. Primary antibodies against LC3 (1:5,000; Saint-Louis, MO, USA), pro-Caspase 3 (1:500; H-227 sc-7148, Santa Cruz, Saint Louis, USA) and GAPDH (1:10000; Millipore) were followed by horseradish peroxidase-conjugated anti-rabbit secondary antibodies (1:10,000; Sigma-Aldrich, Saint-Louis, MO, USA). GAPDH level was used to evaluate protein loading.

\section{Autophagy inhibition}

$5 \times 10^{5}$ HCT116 cells were grown in 6-well plates and incubated with 10nM 3-methyladenine

(3-MA) (M9281, Sigma-Aldrich, Saint-Louis, MO, USA) and 0 or $4 \mathrm{MBq} / \mathrm{mL}$ of ${ }^{125} \mathrm{I}-\mathrm{mAbs}$ 
for 2 days. Cell viability was then estimated by clonogenic assay and expressed as a function of the mean nucleus absorbed dose.

\section{Apoptosis}

$5 \times 10^{5}$ HCT116 cells were grown in 6-well plates containing $1 \mathrm{~mL}$ of medium and exposed to 0 and $4 \mathrm{MBq} / \mathrm{mL}$ of ${ }^{125} \mathrm{I}-\mathrm{mAbs}$ for 2 days. Cells incubated with $0.3 \mu \mathrm{M}$ staurosporine were used as positive control. At day 1 and 2, supernatants were collected in tubes and mixed with the cells after trypsinization. Apoptosis was detected by using the Annexin V-FITC/7-AAD kit (Beckam Coulter, CA, USA) as described in [17]. Caspase 3 was measured using the Caspase-3/CPP32 Colorimetric Assay Kit (K106, Biovision, Lyon, France).

\section{Medium transfer experiments and $\gamma$-H2AX immunofluorescent measurement}

In order to assess the role of bystander in ${ }^{125} \mathrm{I}$-mAbs efficacy, $2 \times 10^{4}$ cells ("donor cells") grown on coverslip were exposed for 2 days to 0 and $4 \mathrm{MBq} / \mathrm{mL}$ of ${ }^{125} \mathrm{I}-\mathrm{mAbs}$. Cells were next washed twice with PBS and were incubated for two hours in the presence of fresh culture medium. Then, medium was transferred to "recipient" cells grown on coverslips. $\gamma-\mathrm{H} 2 \mathrm{AX}$ foci were then measured in both donor and recipient cells by immunofluorescence assays. For this purpose, cells were washed twice with PBS and fixed in $3.7 \%$ formaldehyde in PBS for $30 \mathrm{~min}$. They were then permeabilized at room temperature for $30 \mathrm{~min}$ using PBS/Triton $(0.5 \%)$. Cells were next washed twice with PBS, saturated with PBS/BSA $(1 \mathrm{mg} / \mathrm{ml})$ for 1hour before incubation overnight with anti $\gamma$-H2AX (1:200 PBS/BSA; Merck Millipore). Next, coverslips were incubated for $1 \mathrm{~h}$ in the dark with FITC-labeled goat anti-mouse Ig (Sigma) in PBS-BSA and next washed three times with PBS-BSA and once with PBS before analysis.

\section{Statistical analysis}

A linear mixed regression model (LMRM) was used to determine the relationship between clonogenic survival and mean absorbed dose delivered to the cell nucleus as described in [22]. 
The coefficients of the model were estimated by maximum likelihood and considered significant at the 0.05 level. LMRM was also used to compare the dose-response relationships in the different models. Reference values, such as the doses that led to $37 \%, 50 \%$ and $75 \%$ survival, were also determined.

\section{RESULTS}

\section{Lack of p53 sensitizes HCT116 cells to internalizing ${ }^{125}$ I-mAbs but not to non- internalizing ${ }^{125} \mathrm{I}-\mathrm{mAbs}$}

To investigate the role of $\mathrm{p} 53$ in the cell response to RIT, the survival of $p 53^{-/-}$and $p 53^{+/+}$ HCT116 cells exposed to increasing activities of non-internalizing anti-CEA (35A7) or internalizing anti-HER1 (m225) ${ }^{125}$ I-mAbs was measured. Survival was first expressed as a function of the ${ }^{125} \mathrm{I}-\mathrm{mAb}$ test activity (Fig. 1A) in the culture medium, but this is not indicative of the activity of ${ }^{125} \mathrm{I}-\mathrm{mAbs}$ bound to the cell receptors. Therefore, the radioactivity uptake by $p 53^{-/}$and $p 53^{+/+}$HCT116 cells at day $0,1,2,3$ and 6 following exposure to up to $4 \mathrm{MBq} / \mathrm{mL}$ was determined (Fig. 2A) and the total cumulative radioactivity uptake per cell $\left(\tilde{A}_{r s}\right.$, in Bq.s/cell) was calculated as described in [22]. Flow cytometry analysis of HCT116 cells indicated a lower level of CEA receptors compared to HER1 receptors (Fig. 2B). Expressing survival as a function of $\tilde{A}_{r s}$ showed that non-internalizing anti-CEA ${ }^{125}$ I-mAbs were much more cytotoxic than anti-HER $1{ }^{125} \mathrm{I}-\mathrm{mAbs}$ in both $p 53^{-/-}$and $p 53^{+/+}$HCT116 cells (Fig. 1B), despite having a much lower $\tilde{A}_{r s}\left(2.9 \times 10^{3}\right.$ decay/cell $)$ than anti-HER1 ${ }^{125} \mathrm{I}-\mathrm{mAbs}\left(5.8 \times 10^{4}\right.$ decay/cell) (the value for the PX ${ }^{125} \mathrm{I}-\mathrm{mAb}$ was negligible). Similarly, anti-CEA ${ }^{125} \mathrm{I}-\mathrm{mAbs}$ were more toxic than anti-HER $1{ }^{125} \mathrm{I}-\mathrm{mAbs}, \mathrm{p}<0.001$ ) (Fig. 1C) also when clonogenic survival was expressed as a function of the mean nucleus absorbed dose (the reference parameter in radiobiology). The absorbed doses were calculated for $p 53^{-/}$and $p 53^{+/+}$HCT116 cells using 
both the $S$-values (Table 1) and $\tilde{A}_{r s}$ according to the MIRD cellular formalism and ranged from 0 to 1.2 Gy for anti-CEA ${ }^{125}$ I-mAbs and from 0 to 43 Gy for anti- HER $1{ }^{125}$ I-mAbs.

Finally, concerning the cell p53 status, no significant difference in survival was observed in $p 53^{-/}$and $p 53^{+/+}$HCT116 cells exposed to anti-CEA ${ }^{125} \mathrm{I}-\mathrm{mAbs}(\mathrm{p}=0.639$; D \% values in Table 2). Conversely, $p 53^{-/}$HCT116 cells were more sensitive than $p 53^{+/+}$cells to anti-HER1 ${ }^{125} \mathrm{I}-\mathrm{mAbs}(\mathrm{p}=0.012 ; \mathrm{D} \%$ values in Table 2).

\section{Cells exposed to ${ }^{125}$ I-mAbs die from mitotic death}

After 2 days of RIT, apoptosis was induced in $p 53^{+/+}$HCT116 cells as revealed by flow cytometry analysis and measurement of pro-Caspase 3 (Fig. 3A and 3B) and Caspase 3 expression (Supplementary Fig. 1) but was not detected in $p 53^{--}$HCT116 cells. To confirm the role of p53 and of apoptosis in RIT with ${ }^{125} \mathrm{I}-\mathrm{mAbs}$, we also measured apoptosis induction in A-431 and SK-OV-3 cells exposed to ${ }^{125}$ I-mAbs (Supplementary Fig. 2). These two cell lines are more sensitive to non-internalizing anti-CEA than to internalizing anti-HER2/HER1 ${ }^{125} \mathrm{I}-\mathrm{mAbs}[22]$. As observed with HCT116 cells, apoptosis was induced in $p 53^{+/+} \mathrm{A}-431$ cells (Supplementary Fig. 2), but not in SK-OV-3 cells, which are $p 53^{-/}$[31] (Supplementary Fig. 2). However, p53 activation and p53-related apoptosis do not play a major role in the toxicity of non-internalizing ${ }^{125} \mathrm{I}-\mathrm{mAbs}$, because, and differently from internalizing m $225{ }^{125} \mathrm{I}-\mathrm{mAbs}$, no difference in the survival of $p 53^{-/}$and $p 53^{+/+}$HCT116 cells upon treatment with anti-CEA ${ }^{125} \mathrm{I}-\mathrm{mAbs}$ was observed (Fig. 1B and 1C).

Autophagy induction was next assessed (Fig. 4A and 4B). A decrease in LC3-II was observed as early as $3 \mathrm{~h}$ after exposure to radiolabelled mAbs, but was then followed by induction of LC3-II expression. Induction of autophagy was comparable in $p 53^{-/-}$and $p 53^{+/+}$HCT116 cells. However, its inhibition with 3-MA did not modify survival after exposure to ${ }^{125} \mathrm{I}-\mathrm{mAbs}$, 
whatever the p53 status of the cells (Fig. 5A and 5B), suggesting that autophagy is not involved in the higher cytotoxicity of non-internalizing ${ }^{125} \mathrm{I}-\mathrm{mAbs}$.

To investigate the role of mitotic death in ${ }^{125} \mathrm{I}-\mathrm{mAbs}$ efficacy, the cumulative micronuclei $(\mathrm{MN})$ frequency, which is indicative of the outcome of error-prone DNA repair mechanisms, was determined in $p 53^{-/-}$and $p 53^{+/+}$HCT116 cells at $24 \mathrm{~h}, 48 \mathrm{~h}$ and $72 \mathrm{~h}$ following incubation with $0,1,2$ and $4 \mathrm{MBq} / \mathrm{mL}{ }^{125} \mathrm{I}-\mathrm{mAbs}$ (Fig. 6). Although the MN background level was slightly higher in $p 53^{-/}$than in $p 53^{+/+}$HCT 116 cells, no significant difference in MN formation $(\mathrm{p}=0.2235$ for non-internalizing anti-CEA and $\mathrm{p}=0.4094$ for internalizing antiHER $1{ }^{125}$ I-mAbs) was observed in the two cell lines following RIT. This observation could be linked to the comparable survival values after exposure to $4 \mathrm{MBq} / \mathrm{mL}$ of internalizing or noninternalizing ${ }^{125} \mathrm{I}-\mathrm{mAbs}$, suggesting that RIT induces mitotic cell death in both $p 53^{-/}$and $p 53^{+/+}$HCT116 cells. However, for each cell line, we showed a dose-dependent increase in MN yield in both cell lines, suggesting that mitotic death could be involved in ${ }^{125} \mathrm{I}-\mathrm{mAbs}$ efficacy.

\section{${ }^{125}$ I-mAbs and bystander effects}

We showed, using standard medium transfer experiments, that $\gamma$-H2AX foci were induced in both donor cells exposed to ${ }^{125 \mathrm{I}} \mathrm{I}-\mathrm{mAbs}$ targeting HER2 or CEA and in recipient cells (Fig.7). Though the number of foci/cell was lower in receiving than in donor cells, it was significantly higher than in control cells. These results indicate that bystander effects would be involved in the effects of Auger electrons targeting cell membrane or cytoplasm.

\section{DISCUSSION}

As the cell response to ionizing radiation in conventional external beam radiation therapy (CEBRT) is mainly triggered by nuclear DNA damage, we hypothesized that the energy 
deposited in the nucleus (i.e., the mean nucleus absorbed dose) was the reference parameter also for explaining survival of cells targeted by RIT. However, here we show that, in $p 53^{-/}$ and $p 53^{+/+}$HCT116 cells, different mean nucleus absorbed doses (1. 2 for anti-CEA and 43 Gy for anti-HER $1{ }^{125} \mathrm{I}-\mathrm{mAbs}$ ) can lead to similar toxicity, indicating that ${ }^{125} \mathrm{I}$-mAbs targeting the cell surface are more cytotoxic per Gy than ${ }^{125} \mathrm{I}-\mathrm{mAbs}$ internalized in the cytoplasm. The higher toxicity of anti-CEA ${ }^{125} \mathrm{I}-\mathrm{mAbs}$ is evident when survival is expressed as a function of the mean nucleus absorbed dose or of the total number of cumulative decays ( $\left.\tilde{A}_{r s}\right)$, suggesting that this observation does not depend on the cellular dosimetric approach. These results are in agreement with our previous in vitro and in vivo data obtained in A-431 and SK-OV-3 carcinoma cells $[2,22,25]$ showing the efficacy of anti-CEA ${ }^{125} \mathrm{I}-\mathrm{mAbs}$ for the treatment of small solid CEA-expressing tumors. These findings raise important questions about the mechanisms involved in ${ }^{125} \mathrm{I}-\mathrm{mAbs}$ efficacy and the role of extra-nuclear targets because the cytotoxicity of Auger electron emitters is usually linked to their nuclear localization. Similarly, it is also important to understand why non-internalizing anti-CEA ${ }^{125} \mathrm{I}-\mathrm{mAbs}$ are more cytotoxic per Gy than internalizing anti-HER $1^{125} \mathrm{I}-\mathrm{mAbs}$, which should theoretically be more cytotoxic because closer to the nucleus. It must be also underscored that dehalogenation process occurring in cytoplasm of cells with internalizing mAbs radiolabeled with halogens like ${ }^{125} \mathrm{I}$ [27] does not amend our observations. Indeed, in our study, dehalogenation phenomena are probably partly compensated by continuous uptake of radioactivity due to cell surface HER1 receptor recycling since final activity of internalizing anti-HER $1{ }^{125}$ I-mAbs in tumor cells is quite high (Figure 2).

Energy deposition calculation (Fig. 8) shows that only a very small fraction of the energy released by decay of ${ }^{125}$ I-labelled non-internalizing and internalizing ${ }^{125} \mathrm{I}-\mathrm{mAbs}$ can effectively reach the nucleus. Most of the energy is released within the first nm around the decay site: at the cell membrane for non-internalizing ${ }^{125} \mathrm{I}-\mathrm{mAbs}$, or within the cytoplasm 
(particularly the lysosomes) for internalizing ${ }^{125} \mathrm{I}-\mathrm{mAbs}$. As ${ }^{125} \mathrm{I}-\mathrm{mAbs}$ were more toxic when located at the cell membrane than within cytoplasm (Fig. 1), we next investigated the role of the cell membrane in RIT-induced cell death. Its involvement in cell death in CEBRT has been described in many studies (for reviews [8]). In particular, stimulation of cell membrane death receptors (Fas/CD95, KILLER/DR5, and the CD95/Fas ligand) leads to Caspase activation through the recruitment of proteins involved in the death-inducing signaling complex (DISC). Cell membrane can also be involved through direct activation by radiation of acid sphingomyelinase signaling and production of ceramide, a $2^{\text {nd }}$ messenger of apoptosis [9].

However, our study shows that apoptosis does not play a significant role in ${ }^{125} \mathrm{I}-\mathrm{mAbs}$ efficacy and cannot explain the higher toxicity of non-internalizing ${ }^{125} \mathrm{I}-\mathrm{mAbs}$ than internalizing ${ }^{125} \mathrm{I}-$ mAbs in different cancer cell lines (HCT116, A-431 and SK-OV-3 cells) and whatever their p53 status. However, lack of $p 53$ sensitized HCT116 cells to internalizing anti-HER1 ${ }^{125}$ ImAbs (Table 2) but not to non-internalizing anti-CEA ${ }^{125} \mathrm{I}-\mathrm{mAbs}$, suggesting that different pathways may be involved in the cytotoxicity of anti-CEA and anti-HER1 ${ }^{125}$ I-mAbs. As the final localization of internalizing ${ }^{125} \mathrm{I}-\mathrm{mAbs}$ and of the associated energy deposit is the cytoplasm (lysosomes), p53 might participate in the cytotoxicity of anti-HER1 ${ }^{125}$ I-mAbs through a DNA-mediated process. Conversely, most of the biological effects induced by noninternalizing ${ }^{125} \mathrm{I}$-mAbs might involve non-DNA-mediated mechanisms that are initiated at the cell membrane. In addition, it must be noted that internalizing anti-HER1 mAbs interact with cell membrane receptors upon binding to their receptor before their internalization within the cytoplasm. Therefore, part of their cytotoxicity could be due to their transition through the membrane and its subsequent irradiation.

We next investigated the contribution of other radiation-induced cell death mechanisms. On the basis of preliminary results (unpublished data), radiation-induced necrosis, which is 
observed at high dose, and senescence could be excluded. Conversely, autophagy and mitotic cell death were further investigated. Although a controversial role of autophagy in radiationinduced effects has been reported (for reviews [8,30]), it did not seem to be involved in ${ }^{125} \mathrm{I}-$ mAbs efficacy, since the use of 3-MA, a phosphatidylinositol 3 kinase inhibitor that prevents the formation of autophagosomes, did not modify the cell response to both types of ${ }^{125} \mathrm{I}-\mathrm{mAbs}$, whatever the p53 status of the cells. By contrast, micronuclei were similarly produced in both $p 53^{-/}$and $p 53^{+/+}$cells exposed to ${ }^{125} \mathrm{I}-\mathrm{mAbs}$ and could explain the similar survival rates (Fig.1C). However, it must be noted that the cumulative micronuclei frequency was not related to the mean nucleus absorbed dose (for example similar yield was observed for $1.2 \mathrm{~Gy}$ and 43 Gy) and could be a late event due to radiation-induced biological bystander effects. This is supported by the measurement of $\gamma$-H2AX foci in bystander cells (Fig. 7). Mitotic death could then be the major cell death mechanism mediated by bystander effects. The occurrence of paracrine phenomenon might contribute to the understanding of the efficacy of ${ }^{125} \mathrm{I}-\mathrm{mAbs}$ in reducing growth of millimeter size tumors [2,25] while range of Auger electrons ranges from $\mathrm{nm}$ to $\mu \mathrm{m}$.

In conclusion, we showed that non-internalizing ${ }^{125} \mathrm{I}$-anti CEA mAbs are more cytotoxic than internalizing ${ }^{125} \mathrm{I}-\mathrm{mAbs}$. Moreover, the cell response to non-internalizing ${ }^{125} \mathrm{I}-\mathrm{mAbs}$ is p53independent, whereas in the absence of p53, cells become more sensitive to the effects of internalizing ${ }^{125} \mathrm{I}-\mathrm{mAb}$. Apoptosis and autophagy cannot explain the higher cytotoxicity of ${ }^{125} \mathrm{I}$-mAbs targeting the cell membrane, while mitotic death could be the major process involved. The precise mechanisms involved in bystander effects mediated either by cytoplasmic or membrane irradiation needs now to be investigated. 


\section{ACKNOWLEDGMENTS}

The authors would like to thank Dr Jean-Marc Brondello, Dr Maguy Del Rio and Dr Celine Gongora for helpful discussions. This work was supported by the Institut National du Cancer, grant R09080FF / RPT09005FFA. 


\section{FIGURE LEGENDS}

Fig. 1. Survival. Clonogenic survival was assessed in $p 53^{+/+}$and $p 53^{-/-}$HCT116 cells following exposure to test activities of ${ }^{125} \mathrm{I}-\mathrm{mAbs}$ that gradually increased from 0 to 4 $\mathrm{MBq} / \mathrm{mL}$ for 2 days. Cells were targeted with non-internalizing ${ }^{125} \mathrm{I}-35 \mathrm{~A} 7$ (anti-CEA), internalizing ${ }^{125} \mathrm{I}-\mathrm{m} 225$ (anti-HER1), or non-targeting ${ }^{125} \mathrm{I}-\mathrm{PX}$ mAbs. (A) Survival was expressed as a function the test activities. (B) Survival was expressed as a function the total cumulative radioactivity uptake $\tilde{A}_{r s}$. (C) Survival was expressed as a function the mean nucleus absorbed dose. Results are the mean of four experiments done in triplicate.

Fig. 2. Uptake of radioactivity. (A) Uptake of radioactivity (UOR) per cell (Bq/cell) was measured in HCT116 cells exposed to test activities ranging from 0 to $4 \mathrm{MBq} / \mathrm{mL}$, as indicated, for 6 days. UOR values were the results of measures carried out in both $p 53^{+/+}$and $p 53^{-/}$cells since no effect of p53 on UOR was observed. Results are the mean of five experiments done in sextuplicate. (B) Flow cytometry analysis indicated lower level of expression of CEA compared to EGFR receptors at surface of HCT116 cells.

Fig. 3. RIT-induced apoptosis. (A) Pro-caspase 3 expression was assessed in $p 53^{+/+}$and $p 53^{-}$ ${ }^{/-} \mathrm{HCT} 116$ cells at various time following exposure to 0 and $4 \mathrm{MBq} / \mathrm{mL}$ of internalizing ${ }^{125} \mathrm{I}-$ m225 (anti-HER1) or non-internalizing ${ }^{125}$ I-35A7 (anti-CEA) mAbs. (B) Apoptosis was measured by flow cytometry analysis in $p 53^{+/+}$and $p 53^{-/-}$HCT 116 cells at day 2 following exposure to 0 and $4 \mathrm{MBq} / \mathrm{mL}$ of internalizing ${ }^{125} \mathrm{I}-\mathrm{m} 225$ (anti-HER1), non-internalizing ${ }^{125} \mathrm{I}$ $35 \mathrm{~A} 7$ (anti-CEA) or non-targeting ${ }^{125} \mathrm{I}-\mathrm{PX}$ mAbs. Staurosporine (Staurop.) was used as positive control. Grey boxes represent the $25^{\text {th }}$ to $75^{\text {th }}$ percentiles with the medians as black lines, whiskers marking the range. 
Fig. 4. RIT-induced autophagy. Autophagy induction was assessed by analyzing the expression of LC3-I and LC3-II by western blotting in (A) $p 53^{+/+}$and (B) $p 53^{-/-}$HCT116 cells. Equal loading is shown by GAPDH expression.

Fig. 5. Inhibition of RIT-induced autophagy with 3-methyladenine does not influence cell survival. (A) $p 53^{+/+}$and (B) $p 53^{-/-}$HCT116 cells were grown in 6-well plates and incubated with 0 or $4 \mathrm{MBq} / \mathrm{mL}$ of ${ }^{125} \mathrm{I}-\mathrm{mAbs}$ in the presence, or not, of $10 \mathrm{nM}$ 3-methyladenine (3-MA) for 2 days. Results are the mean of three experiments done in triplicate.

Fig. 6. Cumulative micronucleus frequency. (A) $p 53^{+/+}$and (B) $p 53^{-/-}$HCT116 cells were exposed to $0,1,2$ and $4 \mathrm{MBq} / \mathrm{mL}$ of internalizing ${ }^{125} \mathrm{I}-\mathrm{m} 225$ (anti-HER1), non-internalizing ${ }^{125} \mathrm{I}-35 \mathrm{~A} 7$ (anti-CEA) or ${ }^{125} \mathrm{I}-\mathrm{PX}$ mAbs. Micronuclei occurrence was determined in 500 binucleated cells at day 1,2 and 3 of incubation and their cumulative frequency during three days was determined.

Fig.7. Immunofluorecent detection of $\gamma-\mathrm{H} 2 \mathrm{AX}$ in bystander cells.

"Donor cells" were grown on coverslip and exposed for 2 days to 0 and $4 \mathrm{MBq} / \mathrm{mL}$ of ${ }^{125} \mathrm{I}-$ mAbs. Cells were next washed twice with PBS and incubated for two hours in the presence of fresh culture medium. Then, medium was transferred to "recipient" cells grown on coverslips. $\gamma$-H2AX foci were measured in both (A) donor and (B) recipient cells by immunofluorescence assays exposed to ${ }^{125} \mathrm{I}-\mathrm{mAbs}$.

Fig. 8. Energy deposition associated with anti-CEA ${ }^{125}$ I-mAbs. Representation of the highly localized ${ }^{125}$ I energy deposition in a 5.6 $\mu \mathrm{m}$ sphere surface that corresponds to the mean HCT116 cell radius. Most of the energy is deposited in the first ten nanometers of the sphere.

The cell surface localization of the anti-CEA mAb is also shown by immunofluorescence after $1 \mathrm{~h}$ incubation of HCT116 cells with the antibody (inset).

Supplementary Fig. 1. Caspase 3 expression in $p 53^{+/+}$HCT116 cells at day 1 and 2 following exposure to 0 and $4 \mathrm{MBq} / \mathrm{mL}$ of internalizing ${ }^{125} \mathrm{I}-\mathrm{m} 225$ (anti-HER1), non- 
internalizing ${ }^{125} \mathrm{I}-35 \mathrm{~A} 7$ (anti-CEA) or non-targeting ${ }^{125} \mathrm{I}-\mathrm{PX}$ mAbs. Staurosporine (Staurop.) was used as positive control.

Supplementary Fig. 2. Induction of apoptosis in A-431 and SK-OV-3 cells. Apoptosis was detected in A-431 and SK-OV-3 cells exposed to 0 and $4 \mathrm{MBq} / \mathrm{mL}$ of internalizing ${ }^{125} \mathrm{I}-\mathrm{m} 225$ $\left({ }^{125} \mathrm{I}\right.$-Trastuzumab for SK-OV-3 cells), non-internalizing ${ }^{125} \mathrm{I}$-35A7 or non-targeting ${ }^{125} \mathrm{I}-\mathrm{PX}$ mAbs. Staurosporine (Staurop.) was used as positive control. Grey boxes represent the $25^{\text {th }}$ to $75^{\text {th }}$ percentiles with the medians as black lines, whiskers marking the range. 


\section{REFRENCES}

[1] Balagurumoorthy P, Xu X, Wang K, Adelstein SJ Kassis AI. Effect of distance between decaying (125)I and DNA on Auger-electron induced double-strand break yield. Int J Radiat Biol 2012.

[2] Boudousq V, Ricaud S, Garambois V, et al. Brief intraperitoneal radioimmunotherapy of small peritoneal carcinomatosis using high activities of noninternalizing 125Ilabeled monoclonal antibodies. J Nucl Med 2010;51:1748-1755.

[3] Buchegger F, Perillo-Adamer F, Dupertuis YM Delaloye AB. Auger radiation targeted into DNA: a therapy perspective. Eur J Nucl Med Mol Imaging 2006;33:1352-1363.

[4] Cornelissen B Vallis KA. Targeting the nucleus: an overview of Auger-electron radionuclide therapy. Curr Drug Discov Technol 2010;7:263-279.

[5] Eriksson D Stigbrand T. Radiation-induced cell death mechanisms. Tumour Biol 2010;31:363-372.

[6] Feinendegen LE. The Auger Effect in biology and medicine. Looking back. Int J Radiat Biol 2012.

[7] Goddu SM, Howell RW, Bouchet LG, Bolch WE Rao DV. MIRD Cellular S values:Self-absorbed Dose per Unit Cumulated Activity for Selected Radionclides and Monoenergetic Electron and Alpha Particle Emitters Incorporated into Different Cell Compartments. Reston, VA:Society of Nuclear Medicine 1997.

[8] Golden EB, Pellicciotta I, Demaria S, Barcellos-Hoff MH Formenti SC. The convergence of radiation and immunogenic cell death signaling pathways. Front Oncol 2012;2:88.

[9] Haimovitz-Friedman A, Kan CC, Ehleiter D, et al. Ionizing radiation acts on cellular membranes to generate ceramide and initiate apoptosis. J Exp Med 1994;180:525-535.

[10] Hammarstrom S, Shively JE, Paxton RJ, et al. Antigenic sites in carcinoembryonic antigen. Cancer Res 1989;49:4852-4858.

[11] Howell RW. Auger processes in the 21st century. Int J Radiat Biol 2008;84:959-975.

[12] Kassis AI. Radiotargeting agents for cancer therapy. Expert Opin drug deliv 2005;2:981-991.

[13] Kassis AI, Fayad F, Kinsey BM, Sastry KS Adelstein SJ. Radiotoxicity of an 125Ilabeled DNA intercalator in mammalian cells. Radiat Res 1989;118:283-294.

[14] Kassis AI, Fayad F, Kinsey BM, Sastry KS, Taube RA Adelstein SJ. Radiotoxicity of 125I in mammalian cells. Radiat Res 1987;111:305-318.

[15] Kohler G, Howe SC Milstein C. Fusion between immunoglobulin-secreting and nonsecreting myeloma cell lines. Eur J Immunol 1976;6:292-295.

[16] Li L, Quang TS, Gracely EJ, et al. A Phase II study of anti-epidermal growth factor receptor radioimmunotherapy in the treatment of glioblastoma multiforme. J Neurosurg 2010;113:192-198.

[17] Paillas S, Causse A, Marzi L, et al. MAPK14/p38alpha confers irinotecan resistance to TP53-defective cells by inducing survival autophagy. Autophagy 2012;8.

[18] Palanca-Wessels MC Press OW. Improving the efficacy of radioimmunotherapy for non-Hodgkin lymphomas. Cancer 2010;116:1126-1133.

[19] Pomplun E. Auger electron spectra--the basic data for understanding the Auger effect. Acta Oncol 2000;39:673-679.

[20] Pomplun E, Booz J Charlton DE. A Monte Carlo simulation of Auger cascades. Radiat Res 1987;111:533-552. 
[21] Pouget JP, Navarro-Teulon I, Bardies M, et al. Clinical radioimmunotherapy--the role of radiobiology. Nat Rev Clin Oncol 2011;8:720-734.

[22] Pouget JP, Santoro L, Raymond L, et al. Cell membrane is a more sensitive target than cytoplasm to dense ionization produced by auger electrons. Radiat Res 2008;170:192200.

[23] Prise KM, Schettino G, Folkard M Held KD. New insights on cell death from radiation exposure. Lancet Oncol 2005;6:520-528.

[24] Quang TS Brady LW. Radioimmunotherapy as a novel treatment regimen: 125Ilabeled monoclonal antibody 425 in the treatment of high-grade brain gliomas. Int $\mathbf{J}$ Radiat Oncol Biol Phys 2004;58:972-975.

[25] Santoro L, Boutaleb S, Garambois V, et al. Noninternalizing monoclonal antibodies are suitable candidates for 125I radioimmunotherapy of small-volume peritoneal carcinomatosis. J Nucl Med 2009;50:2033-2041.

[26] Seidl C, Port M, Gilbertz KP, et al. 213Bi-induced death of HSC45-M2 gastric cancer cells is characterized by G2 arrest and up-regulation of genes known to prevent apoptosis but induce necrosis and mitotic catastrophe. Mol Cancer Ther 2007;6:23462359.

[27] Vaidyanathan G, Affleck DJ, Bigner DD Zalutsky MR. Improved xenograft targeting of tumor-specific anti-epidermal growth factor receptor variant III antibody labeled using N-succinimidyl 4-guanidinomethyl-3-iodobenzoate. Nucl Med Biol 2002;29:111.

[28] Welt S, Divgi CR, Real FX, et al. Quantitative analysis of antibody localization in human metastatic colon cancer: a phase I study of monoclonal antibody A33. J Clin Oncol 1990;8:1894-1906.

[29] Welt S, Scott AM, Divgi CR, et al. Phase I/II study of iodine 125-labeled monoclonal antibody A33 in patients with advanced colon cancer. J Clin Oncol 1996;14:17871797.

[30] Wu WK, Coffelt SB, Cho $\mathrm{CH}$, et al. The autophagic paradox in cancer therapy. Oncogene 2012;31:939-953.

[31] Yaginuma Y Westphal H. Abnormal structure and expression of the p53 gene in human ovarian carcinoma cell lines. Cancer Res 1992;52:4196-4199.

[32] Yasui LS. Molecular and Cellular Effects of Auger Emitters: 2008-2011. Int J Radiat Biol 2012. 